\title{
molecules
}

ISSN 1420-3049

www.mdpi.com/journal/molecules

Article

\section{Synthesis and Pharmacological Evaluation of Novel Benzenesulfonamide Derivatives as Potential Anticonvulsant Agents}

\section{Zhiming Wang ${ }^{\dagger}$, Jinping Li ${ }^{\dagger}$, Xiao-Dong Zeng, Xian-Ming Hu, Xiaoju Zhou * and Xuechuan Hong *}

State Key Laboratory of Virology, Key Laboratory of Combinatorial Biosynthesis and Drug Discovery, Ministry of Education, Wuhan University School of Pharmaceutical Sciences, 185 Donghu Road, Wuhan 430071, China; E-Mails: zhiming.wang@whu.edu.cn (Z.W.); lijinping19891210@126.com (J.L.); zxd201102@whu.edu.cn (X.-D.Z.); xmhu@whu.edu.cn (X.-M.H.)

$\dagger$ These authors contributed equally to this work.

* Authors to whom correspondence should be addressed; E-Mails: xjzhou@whu.edu.cn (X.Z.); xhy78@whu.edu.cn (X.H.); Tel.: +86-27-687-52331 (X.H.); Fax: +86-27-687-59100 (X.H.).

Academic Editor: Maria Emília de Sousa

Received: 30 July 2015 / Accepted: 17 September 2015 / Published: 23 September 2015

\begin{abstract}
A novel series of benzenesulfonamide derivatives containing 4-aminobenzenesulfonamide and $\alpha$-amides branched valproic acid or 2,2-dimethylcyclopropanecarboxylic acid moieties were synthesized and screened for their anticonvulsant activities in mice maximal electroshock seizure (MES) and subcutaneous pentylenetetrazole (scPTZ) test. The activity experimental study showed that 2,2-dipropyl- $N^{1}$-(4-sulfamoylphenyl)malonamide (18b) had the lowest median effective dose (ED 50$)$ of $16.36 \mathrm{mg} / \mathrm{kg}$ in MES test, and 2,2-dimethyl- $N$-(4sulfamoylphenyl)cyclopropane-1,1-dicarboxamide (12c) had the lowest ED 50 of $22.50 \mathrm{mg} / \mathrm{kg}$ in scPTZ test, which resulted in the protective indexe (PI) of 24.8 and 20.4, respectively. These promising data suggest the new compounds have good potential as new class of anticonvulsant agents with high effectiveness and low toxicity for the treatment of epilepsy.
\end{abstract}

Keywords: sulfonamide; anticonvulsant; MES; scPTZ 


\section{Introduction}

Epilepsy is a common neurological disorder that affects approximately 50 million people around the world [1-3]. In spite of the appearance of several novel antiepileptic drugs (AEDs) during the last two decades [4-7], it is still depressing that about $30 \%$ of epileptic patients fail to respond to the existing AEDs [8-10], which makes it necessary to focus on the development of active and safe AEDs accommodating wider range of people.

The clinical utilization of Valproic acid (VPA), one of the most widely used AEDs, is limited by its side effects such as teratogenicity and life-threatening hepatotoxicity [11-13]. The formation of hepatotoxic metabolites with a terminal double bond, 4-ene-VPA, is possibly the main cause of the hepatotoxicity [14,15]. In order to searching for new nonteratogenic and nonhepatotoxic compounds, numerous analogues and derivatives of VPA have been investigated. TMCA (2, Figure 1), a cyclic analogue of VPA, is found to be inactive at the rat anticonvulsant maximal electroshock seizure (MES) $\left(\mathrm{ED}_{50}>150 \mathrm{mg} / \mathrm{kg}\right.$ ) model and can prevent its biotransformation to hepatotoxic metabolites [16,17]. Further studies have revealed that amide derivatives of 2, TMCD (5), especially $N$-methoxy TMCD (MTMCD, 6) and TMC-urea (7) are broad-spectrum anticonvulsants with a much wider safety margin than VPA [18]. In 2008, Jakob reported the synthesis and high potency of TMCD-benzenesulfonamide $\left(3, \mathrm{ED}_{50}=26 \mathrm{mg} / \mathrm{kg}\right)$ along with a wide protective index $\left(\mathrm{PI}=\mathrm{TD}_{50} / \mathrm{ED}_{50}>19\right)$ in the rat-MES test [19]. Recently, it was reported that $\alpha$-fluoronated TMCD (4) was 120 times more potent than VPA in the rat-scMet test $\left(\mathrm{ED}_{50}=6 \mathrm{mg} / \mathrm{kg}\right)$ with a remarkable protective index $(\mathrm{PI}=20)$ [20]. These developments prompted us to focus on systematic structural modifications in the $\alpha$ position. In the current study, we introduced amid groups to the benzenesulfonamide system in order to get novel anticonvulsant agents. In view of the difficulty of synthesis, the 2,2,3,3-tetramethylcyclopropane fragment was replaced by 2,2-dimethylcyclopropane group, which has been proven to be a safe and effective structure in our group's early work [21-26]. Herein, a series of benzenesulfonamide derivatives containing 4-aminobenzenesulfonamide and $\alpha$-amides branched valproic acid or 2,2-dimethylcyclopropanecarboxylic acid moieties were synthesized and their pharmacological activities as potential anticonvulsant agents were evaluated in mice maximal MES and subcutaneous pentylenetetrazole (scPTZ) tests in this paper.

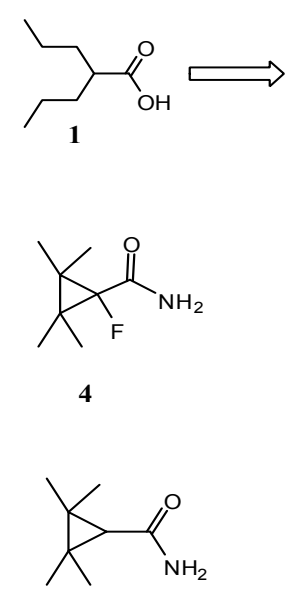

5

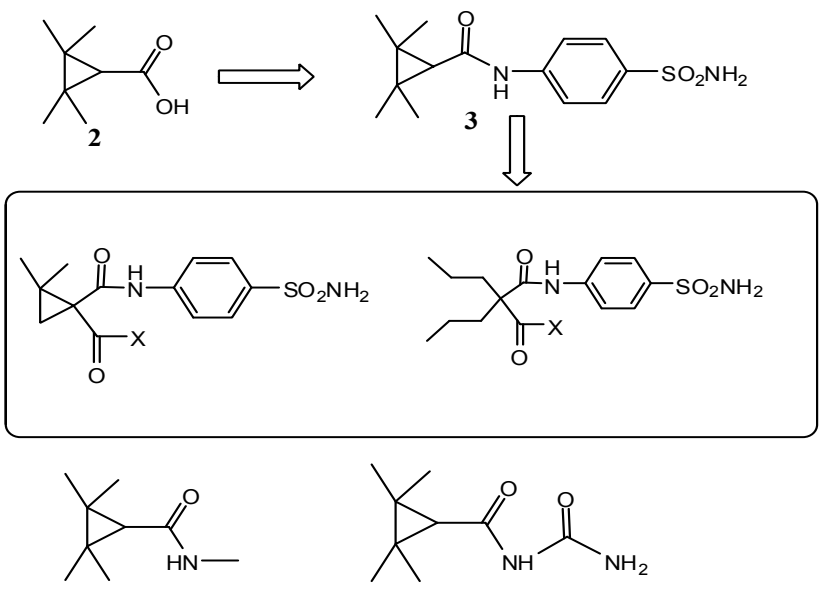

6
7

Figure 1. Structure of AEDs and designed compounds. 


\section{Results and Discussion}

\subsection{Chemistry}

The general synthetic route for compound $\mathbf{1 2}$ is shown in Scheme 1. Compound $\mathbf{8}$, used as the starting material, was reacted with $\mathrm{SOCl}_{2}$ in anhydrous DCM to obtain compound 9. The coupling reaction of compound $\mathbf{9}$ and sulfonamide in the presenve of TEA resulted in the formation of compound $\mathbf{1 0}$ in $80 \%$ yield. Compound 11 was then obtained by hydrolysis of compound 10 in a $1 \mathrm{~mol} / \mathrm{L} \mathrm{NaOH}$ in EtOH-water $(1: 1)$ solution for $12 \mathrm{~h}$. Amidation of compound $\mathbf{1 1}$ with a variety of amines in the EDCI/HOBt system gave the corresponding final products $\mathbf{1 2 a}-\mathbf{n}$ in good yields. The structures of all new compounds were characterized by ${ }^{1} \mathrm{H}-\mathrm{NMR},{ }^{13} \mathrm{C}-\mathrm{NMR}$ and MS. The spectrums were shown in supplementary materials.

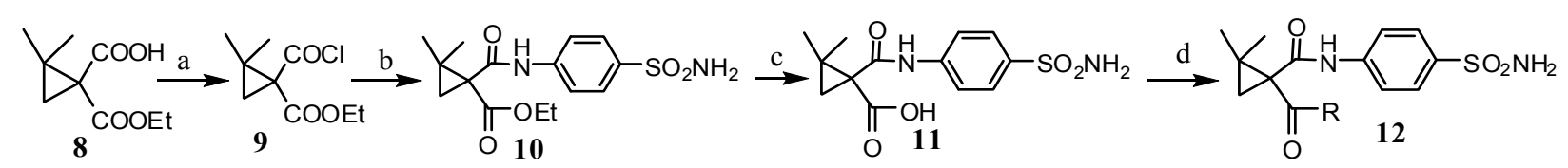

Scheme 1. Synthetic route for the synthesis of compounds 12a-n. Reagents and conditions:

(a) $\mathrm{SOCl}_{2}$, DCM, refluxed, 2 h; (b) TEA, acetone, r.t, 4 h; (c) $\mathrm{NaOH}$, EtOH, r.t, 12 h; and

(d) EDCI, HOBt, DCM/THF, r.t, 12 h (r.t. means room temperature).

The synthetic route of compounds $\mathbf{1 8 a}-\mathbf{c}$ is listed in Scheme 2. It was very similar to that of compounds 12a-n. However, all anilines and secondary amines failed to react with compound $\mathbf{1 7}$. It may be attributed to the steric hindrance of the double propyl branch.

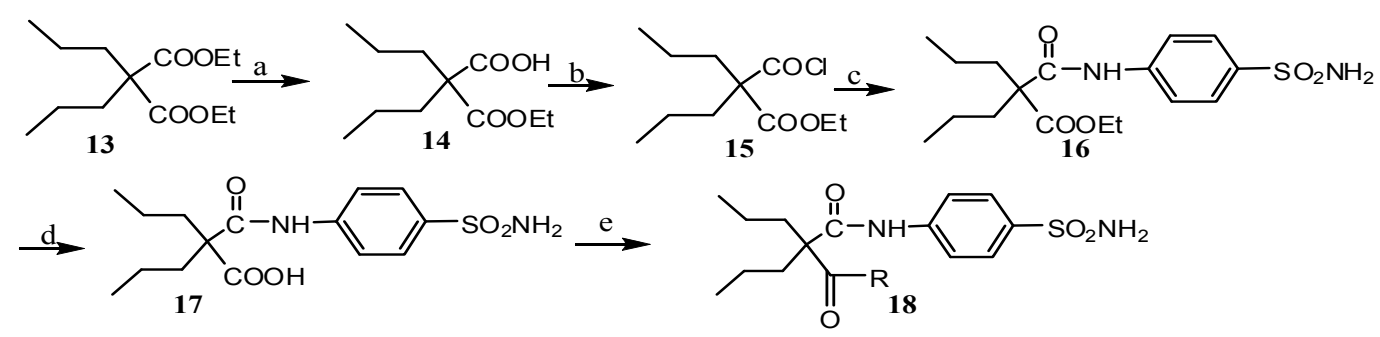

Scheme 2. Synthetic route for the synthesis of compounds 18a-c. Reagents and conditions: (a) $\mathrm{NaOH}$, EtOH, r.t, 12 h; (b) SOCl2, DCM, refluxed, 2 h; (c) TEA, acetone, r.t, 4 h; (d) $\mathrm{NaOH}$, EtOH, r.t, 12 h; and (e) EDCI, HOBt, DCM/THF, r.t, 12 h (r.t. means room temperature).

\subsection{Pharmacological Evaluation}

Chemical diversity and different biological mechanism of anticonvulsant drugs make it difficult to find a common method to identify the candidates. When it comes to develop novel anticonvulsant agents, it is necessary to apply conventional screening or structure modification of these tested compounds. Early identification of anticonvulsant agents is usually conducted via in vivo screening such as MES test and scPTZ test [27-29]. 
In the present study, 22 new synthesized compounds were evaluated following the standard procedure (NIH anticonvulsant drug development program). Those compounds were administrated intraperitoneally (i.p.) to male Kunming mice weighting 18-22 g. In the initial evaluation, the compounds were given at dose of $300 \mathrm{mg} / \mathrm{kg}, 100 \mathrm{mg} / \mathrm{kg}$ and $30 \mathrm{mg} / \mathrm{kg}$. The observations were taken at two time intervals, namely $0.5 \mathrm{~h}$ and $4 \mathrm{~h}$. The acute neurotoxicity was measured by the rotarod test. The results are summarized in Table 1 .

Table 1. Anticonvulsant activity and neurotoxicity of compounds administered intraperitoneally.

\begin{tabular}{|c|c|c|c|c|c|c|c|c|}
\hline \multirow{2}{*}{\multicolumn{2}{|c|}{ Compounds }} & \multicolumn{6}{|c|}{ Intraperitioneal Injection into Mice ${ }^{a}$} & \multirow{3}{*}{$C \log P^{b}$} \\
\hline & & \multicolumn{2}{|c|}{ MES $^{\mathbf{c}}$} & \multicolumn{2}{|c|}{ scPTZ $^{d}$} & \multicolumn{2}{|c|}{ Neurotoxocity ${ }^{\mathrm{e}}$} & \\
\hline No. & $\mathbf{R}$ & $0.5 \mathrm{~h}$ & $4 \mathrm{~h}$ & $0.5 \mathrm{~h}$ & $4 \mathrm{~h}$ & $0.5 \mathrm{~h}$ & $4 \mathrm{~h}$ & \\
\hline 10 & $-\mathrm{OEt}$ & 100 & $-f$ & 300 & - & 300 & - & 1.633 \\
\hline 11 & $-\mathrm{OH}$ & 100 & - & - & - & 300 & - & 0.865 \\
\hline $12 a$ & $-\mathrm{NHC}\left(\mathrm{CH}_{3}\right)_{3}$ & 100 & - & - & - & - & - & 1.484 \\
\hline $12 b$ & $-\mathrm{N}\left(\mathrm{CH}_{2} \mathrm{CH}_{3}\right)_{2}$ & 100 & 300 & - & - & 300 & - & 1.735 \\
\hline $12 \mathrm{c}$ & $-\mathrm{NH}_{2}$ & 30 & 100 & 30 & 100 & 300 & - & -0.019 \\
\hline 12d & $-\mathrm{NHCH}_{3}$ & 30 & 300 & 100 & 300 & - & - & 0.247 \\
\hline $12 \mathrm{e}$ & & 100 & - & - & - & - & - & 1.305 \\
\hline $12 \mathrm{f}$ & & 300 & - & - & - & 300 & - & 3.223 \\
\hline $12 \mathrm{~g}$ & & 300 & 300 & - & - & - & - & 0.797 \\
\hline $12 \mathrm{~h}$ & & 100 & 300 & 300 & - & - & - & 2.503 \\
\hline $12 \mathrm{i}$ & & 100 & - & - & - & - & - & 2.604 \\
\hline $12 j$ & & 100 & - & - & - & - & - & 1.591 \\
\hline $12 k$ & & 100 & - & 300 & - & 300 & - & 1.834 \\
\hline 121 & & - & - & - & - & - & - & 1.032 \\
\hline $12 \mathrm{~m}$ & & 300 & - & - & - & - & - & 3.071 \\
\hline $12 n$ & $\mathrm{H}$ & 100 & 300 & - & - & - & - & 1.021 \\
\hline 16 & $-\mathrm{OEt}$ & 300 & - & - & - & 300 & - & 2.815 \\
\hline 17 & $-\mathrm{OH}$ & 100 & - & 300 & - & 300 & - & 2.046 \\
\hline $18 \mathrm{a}$ & & 100 & 300 & - & - & - & - & 2.203 \\
\hline $18 \mathrm{~b}$ & $-\mathrm{NH}_{2}$ & 30 & 30 & - & - & 300 & - & 1.163 \\
\hline $18 \mathrm{c}$ & $\stackrel{\mathrm{H}}{-\mathrm{N}}$ & 100 & 100 & - & - & - & - & 2.487 \\
\hline & nytoin ${ }^{g}$ & 30 & 30 & - & - & 100 & 100 & \\
\hline & uximide ${ }^{\mathrm{h}}$ & - & - & 100 & 300 & - & - & \\
\hline
\end{tabular}

a: $30 \mathrm{mg} / \mathrm{kg}, 100 \mathrm{mg} / \mathrm{kg}$, and $300 \mathrm{mg} / \mathrm{kg}$ of doses were administered i.p. The data in the table indicate the minimal dose whereby bioactivity was demonstrated. The animals were examined at $0.5 \mathrm{~h}$ and $4.0 \mathrm{~h}$ after injection was administered; ${ }^{\mathrm{b}}$ : Clog P was calculated using software ChemDraw Ultra (version 6.0.1; PerkinElmer Informatics, Waltham, MA, USA); c: Maximal electroshock test; d: Subcutaneous pentylenetetrazole test; e: Neurotoxocity screening; ${ }^{\text {f: }}$ A dash indicates the absence of anticonvulsant activity and neurotoxicity at the maximum dose administered (300 mg/kg); ${ }^{\text {: }}$ Data from Reference [30]; ${ }^{\text {h}}$ : Data from Reference [31].

The initial evaluation of all these compounds, with the exception of 12l, showed anticonvulsant activities in the mice i.p. MES screening. Among 2,2-dimethyl- $N$-(4-sulfamoylphenyl)cyclopropane- 
1,1-dicarboxamide derivatives $(\mathbf{1 2 a}-\mathbf{1 2 n})$, the most active analogs were $12 \mathbf{c}$ and $\mathbf{1 2 d}$, which showed anticonvulsant activities at $0.5 \mathrm{~h}$ after administrated intraperitoneally (i.p.) at a dose of $30 \mathrm{mg} / \mathrm{kg}$ to the male Kunming mice. Furthermore, compound 12c was active at $4 \mathrm{~h}$ at a dose of $100 \mathrm{mg} / \mathrm{kg}$ and had a longer duration, while compound $\mathbf{1 2 d}$ did not show any improvements. The compounds containing aromatic amines substituents such as $\mathbf{1 2 h}$ and $\mathbf{1 2} \mathbf{i}$ acted much better than $\mathbf{1 2 f}$ and $\mathbf{1 2 n}$, which indicated that substituents with the phenyl moiety had significant influence on the anticonvulsant activity. When the substituents at the carboxyl position were alkyl amines, the order of anticonvulsant activity against the MES test was found to be $12 \mathbf{d}>\mathbf{1 2} \mathbf{e}=\mathbf{1 2} \mathbf{n}>\mathbf{1 2 k}=\mathbf{1 2 a}$. It is noteworthy that the anticonvulsant activity of those compounds was decreased when the alkyl moiety possesses more carbons. A double bond was introduced to the branch in compounds $\mathbf{1 2 n}$ and 18a in order to obtain a short-duration anticonvulsant agent like secobarbital, which also contained a carbon-carbon double bond within the molecular structure [32]. Unexpectedly, both compounds 12n and 18a showed the anticonvulsant activity at $4 \mathrm{~h}$ after administrated with a dose of $300 \mathrm{mg} / \mathrm{kg}$. Speaking of the performance of compounds $\mathbf{1 2 c}$ and $\mathbf{1 8 b}$, both containing the same amino-group, compound $\mathbf{1 8 b}$ showed anticonvulsant activity at $4 \mathrm{~h}$ after administrated with a dose of $30 \mathrm{mg} / \mathrm{kg}$, while compound 12c showed anticonvulsant activity with a dose of $100 \mathrm{mg} / \mathrm{kg}$, which may be attributed to the lipophilicity. Meanwhile, when compounds $18 \mathrm{c}$ and 12e were compared, a similar activity was obtained.

In the scPTZ test, only six compounds exhibited protection against induced seizure at $300 \mathrm{mg} / \mathrm{kg}$ or less. Compounds 10, 12h, 12k and 17 showed anticonvulsant activity at $300 \mathrm{mg} / \mathrm{kg}$ after $0.5 \mathrm{~h}$, while compound 12c was more active at $30 \mathrm{mg} / \mathrm{kg}$ after $0.5 \mathrm{~h}$. Compound $12 \mathrm{c}$ was still active after $4 \mathrm{~h}$ at a dose of $100 \mathrm{mg} / \mathrm{kg}$. The result indicated that compound 12c had a rather quick onset and was more active than the positive control drug ethosuximide in the scPTZ screen.

All the tested compounds maintained balance well in the neurotoxicity test at $100 \mathrm{mg} / \mathrm{kg}$ or less. However, compounds $10,11,12 \mathrm{~b}, 12 \mathrm{c}, 12 \mathrm{f}, 12 \mathrm{k}, 16,17$ and $18 \mathrm{~b}$ revealed neurotoxicity at a dose of $300 \mathrm{mg} / \mathrm{kg}$ after $0.5 \mathrm{~h}$ and turned out to be non-toxic after $4 \mathrm{~h}$. All the most active molecules, namely 12c, 12d and 18b, showed anticonvulsant potencies in lower doses than neurotoxic properties. No relation between the activity and the neurotoxocity was found. In other words, better activity did not mean more neurotoxocity.

Crossing the blood-brain barrier (BBB) is an important factor influencing anticonvulsant activity. It is believed that $\mathrm{C} \log \mathrm{P}$ (calculated $\log \mathrm{P}$ ) values between 1 and 2 is sufficient for crossing $\mathrm{BBB}$ and the lipophilicity of the titled compound is very important in the central nervous system drug penetrating through BBB [33]. The ClogP (calculated $\log P$ ) values of the tested compounds were also listed in Table 1. The above data did not show an obvious correlation between $\mathrm{Clog} P$ values and in vivo anticonvulsant activities. The most activity compounds, $\mathbf{1 2 c}$ and 12d, showed relatively lower ClogP of -0.019 and 0.247. These values suggested a low concentration of those compounds in brain.

There are two possible reasons for the existence of anticonvulsant activity. The designed compounds meet a general structural model of AEDs as shown in Figure 2 [34]. At first, the dimethylcyclopropane group or the double propyl branch can act as hydrophobic group to enable the compounds to penetrate through the BBB. At the same time, the amide groups act as hydrogen binding domain, while amino as an electron donor group. On the other hand, these compounds may act as carbonic anhydrase inhibitor. 


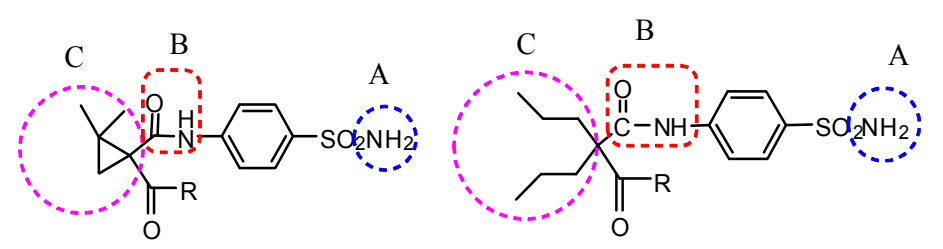

Figure 2. Pharmacophoric structure of designed compounds.

In view of the excellent performance of compounds $12 \mathbf{c}, \mathbf{1 2 d}$ and $\mathbf{1 8 b}$ in the initial screening, they were selected for Phase-II screening. The resulting results for these three molecules were shown in Table 2. Approximated time of peak effects (TPE) of compounds $\mathbf{1 2 c}, \mathbf{1 2 d}$ and $\mathbf{1 8 b}$ were $1 \mathrm{~h}, 1 \mathrm{~h}$ and $2 \mathrm{~h}$, respectively. The quantitative evaluation of pharmacological parameters $\left(\mathrm{ED}_{50}\right.$ and $\left.\mathrm{TD}_{50}\right)$ was performed at TPE after administrated intraperitoneally. Compound $\mathbf{1 8 b}$, the most active compound, showed an ED50 value of $16.36 \mathrm{mg} / \mathrm{kg}$ among the tested compounds in the MES screening. Compound $\mathbf{1 2 d}$ exhibited the lowest toxicity with a TD 50 value $>500 \mathrm{mg} / \mathrm{kg}$. Compound 12c, which turned out to be seven times more active than that of valproate, revealed the best activity in the scPTZ test with an ED50 value of $22.50 \mathrm{mg} / \mathrm{kg}$. All these three compounds mentioned above possessed higher PI than that of standard drugs (e.g., Phenytoin and valproate). Consequently, the higher anticonvulsant activity of compound $\mathbf{1 8 b}(\mathrm{PI}=24.8)$ in the MES test and compound 12c $(\mathrm{PI}=20.4)$ in scPTZ test as compared to VPA and its substantially wider safety margin than VPA and Phenytoin were observed. These observations indicated this benzenesulfonamide derivative containing 4-aminobenzenesulfonamide and the $\alpha$-amide branched valproic acid or 2,2-dimethylcyclopropanecarboxylic acid moiety was a potential candidate as a new AED.

Table 2. Quantitative anticonvulsant data in mice dosed intraperitoneally.

\begin{tabular}{|c|c|c|c|c|c|}
\hline \multirow{2}{*}{ Compound } & \multicolumn{2}{|c|}{ ED $_{50}{ }^{a}$} & \multirow{2}{*}{$\mathbf{T D}_{50}{ }^{b}$} & \multicolumn{2}{|c|}{$\mathbf{P I}^{\mathrm{c}}$} \\
\hline & MES & scPTZ & & MES & scPTZ \\
\hline $12 \mathrm{c}$ & $24.47(20.05-29.83)^{d}$ & $22.50(16.25-31.14)$ & $499.2(455.3-547.4)$ & 20.4 & 22.19 \\
\hline 12d & $25.25(18.14-35.14)$ & $\mathrm{ND}^{\mathrm{e}}$ & $>500$ & $>19.80$ & $\mathrm{ND}^{\mathrm{e}}$ \\
\hline $18 \mathrm{~b}$ & $16.36(14.17-18.89)$ & $\mathrm{ND}^{\mathrm{e}}$ & $406.7(337.7-489.7)$ & 24.85 & $\mathrm{ND}^{\mathrm{e}}$ \\
\hline phenytoin $^{f}$ & $9.5(8.1-10.4)$ & $>300$ & 65.5 & 6.9 & $<0.22$ \\
\hline valproate $^{\mathrm{f}}$ & 272 & 149 & 426 & 1.6 & 2.9 \\
\hline
\end{tabular}

a: Dose in milligrams per kilogram body mass; ${ }^{\text {b: }}$ Minimal toxicity which was determined by rotarod test $30 \mathrm{~min}$ after the test drug was administered; ${ }^{c}$ : Protection index $\left(\mathrm{TD}_{50} / \mathrm{ED}_{50}\right)$; ${ }^{\mathrm{d}}$ : Data in parentheses are the $95 \%$ confidence limits; ${ }^{\text {e: }}$ Not determined; ${ }^{\text {: }}$ Data from Reference [33].

The acute toxicity of compounds $12 \mathrm{c}, \mathbf{1 2 d}$ and $\mathbf{1 8 b}$ were measured and the results were reported in Tables 3 and 4. In the preliminary test, all compounds dosed intragastric administration did not show acute toxicity to kill mice at $2000 \mathrm{mg} / \mathrm{kg}$. Unfortunately, when these compounds were administrated intraperitoneally, some mice died at $500 \mathrm{mg} / \mathrm{kg}$ or $2000 \mathrm{mg} / \mathrm{kg}$. The $\mathrm{LD}_{50}$ values of the tested agents administered intraperitoneally, along with the data on the standard drug (phenytoin), are listed in Table 4. Compound 12c showed a LD 50 of $762.7 \mathrm{mg} / \mathrm{kg}$; compound 12d, the least toxic compound, showed a $\mathrm{LD}_{50}$ of $922.0 \mathrm{mg} / \mathrm{kg}$, while the $\mathrm{LD}_{50}$ value of phenytoin was $100 \mathrm{mg} / \mathrm{kg}$. These results proved that the newly synthesized compounds were safer than the standard drug. When comparing $12 \mathbf{c}$ with $\mathbf{1 8 b}$, it was self-evident that lower $\mathrm{LD}_{50}$ came with lower ED50. 
Table 3. The acute toxicity of compounds in preliminary test.

\begin{tabular}{cccc}
\hline \multirow{2}{*}{ Compound } & \multirow{2}{*}{ Dose $^{\mathbf{a}}$} & \multicolumn{2}{c}{ Administration Route } \\
\cline { 3 - 4 } & & i.g $^{\mathbf{b}}$ & i.p $^{\mathbf{c}}$ \\
\hline \multirow{3}{*}{ 12c } & 2000 & $0 / 5^{\mathrm{d}}$ & $4 / 5$ \\
& 500 & $\mathrm{ND}^{\mathrm{e}}$ & $1 / 5$ \\
& 50 & $\mathrm{ND}$ & $0 / 5$ \\
\hline \multirow{3}{*}{ 12d } & 2000 & $0 / 5$ & $5 / 5$ \\
& 500 & $\mathrm{ND}$ & $1 / 5$ \\
& 50 & $\mathrm{ND}$ & $0 / 5$ \\
\hline \multirow{3}{*}{$\mathbf{1 8 b}$} & 2000 & $0 / 5$ & $5 / 5$ \\
& 500 & $\mathrm{ND}$ & $2 / 5$ \\
& 50 & $\mathrm{ND}$ & $0 / 5$ \\
\hline
\end{tabular}

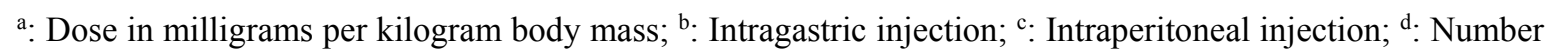
of animals protected/number of animals tested; ${ }^{\text {e: }}$ Not determined.

Table 4. The acute toxicity of compounds in intrapertioneal injection.

\begin{tabular}{cc}
\hline Compound & LD $_{\mathbf{5 0}}{ }^{\mathbf{a}}$ \\
\hline $\mathbf{1 2 c}$ & $762.7(656.8-885.6)$ \\
$\mathbf{1 2 d}$ & $922.0(601.1-1414)$ \\
$\mathbf{1 8 b}$ & $638.0(475.0-857.0)$ \\
phenytoin & $100(94.3-101.2)$ \\
a: Dose in milligrams per kilogram body mass.
\end{tabular}

\section{Experimental Section}

\subsection{General Information}

All commercially available solvents and reagents were purchased from Sigma-Aldrich (St. Louis, MO, USA) and used without further purification. ${ }^{1} \mathrm{H}$ - and ${ }^{13} \mathrm{C}-\mathrm{NMR}$ spectra were recorded on Bruker AV400 MHz spectrometers (Bruker Biospin, Rheinstetten, Germany) in deuteriochloroform $\left(\mathrm{CDCl}_{3}\right)$ unless otherwise stated. All ${ }^{1} \mathrm{H}$ chemical shifts are reported in ppm $(\delta)$ relative to TMS $(0.00) ;{ }^{13} \mathrm{C}$ shifts are reported in $\mathrm{ppm}(\delta)$ relative to $\mathrm{CDCl}_{3}$ (77.0). Data are reported in the following order: chemical shifts are given $(\delta)$; multiplicities are indicated as br (broadened), s (singlet), d (doublet), t (triplet), q (quartet), $\mathrm{m}$ (multiplet), app (apparent); coupling constants, $J$, are reported (Hz); integration is provided. Uncalibrated melting points were taken on XT-4 apparatus (Yuhua Instruments Co., Ltd., Gongyi, Henan, China). Analytical thin-layer chromatography (TLC) was performed on Merck silica gel aluminum sheets (Merck KGaA, Darmstadt, Germany) with F-254 indicator. Visualization was accomplished by UV light, or with solutions of $\mathrm{K}_{2} \mathrm{CO}_{3} / \mathrm{KMnO}_{4}$ in water. Purification by chromatography was performed using 200-300 mesh $\mathrm{SiO}_{2}$ (Qingdao Haiyang Chemical Co., Ltd., Qingdao, Shandong, China) with compressed air as a source of positive pressure. The mass spectra were obtained on Applied Biosystem/MDS-SCIEX API 2000 (AB Sciex Pte. Ltd., Framingham, MA, USA) with Agilent HPLCs, and MicrOTOF-Q orthogonal-accelerated TOF mass spectrometer (Bruker Daltonics, Bremen, Gremany) with an ESI source. Solvents for reactions and chromatography were reagent grade and used as received. "Brine" refers to a saturated aqueous solution of $\mathrm{NaCl}$. 


\subsection{Synthesis}

\subsubsection{Ethyl 1-(Chlorocarbonyl)-2,2dimethylcyclopropanecarboxylate $\mathbf{1 0}$}

Compound $8(1.86 \mathrm{~g})$ was dissolved in $\mathrm{SO}_{2} \mathrm{Cl}_{2}(10 \mathrm{~mL})$ before the mixture was heated to reflux for $2 \mathrm{~h}$. Reaction completion was monitored by TLC analysis. Then, this mixture was cooled to room temperature and concentrated. The resulting oil was dissolved in dry acetone $(10 \mathrm{~mL})$ and was transferred dropwise to a solution of sulfonamide $(1.7 \mathrm{~g})$ in dry acetone $(20 \mathrm{~mL})$ in the presence of $2 \mathrm{Et}_{3} \mathrm{~N}(\mathrm{~mL})$ and catalytic amount of DMAP. The mixture was completed in $4 \mathrm{~h}$ at room temperature. Then, the reaction mixture was diluted with ethyl acetate $(30 \mathrm{~mL})$, the organic layer was washed with $1 \mathrm{~mol} / \mathrm{L} \mathrm{HCl}(10 \mathrm{~mL} \times 2)$, water $(10 \mathrm{~mL} \times 2)$ and brine $(10 \mathrm{~mL})$ subsequently. The organic phase was dried over $\mathrm{MgSO}_{4}$ and concentrated under vacuum. The obtained crude product was purified by column chromatography (EtOAc:Petroleum ether $=1: 1)$ to give the titled compound $\mathbf{1 0}$ as a white solid. Yield: $90 \%$; mp: $138-140{ }^{\circ} \mathrm{C} ;{ }^{1} \mathrm{H}-\mathrm{NMR}$ (400 MHz, DMSO) $\delta 10.40$ (s, -CONH, 1H), 7.86-7.66 (m, 4H, ArH), 7.25 (s, 2H, SO $2 \mathrm{NH}_{2}$ ), 4.21-4.00 (m, 2H, -CH2CH3), 1.38 (d, J=4.8 Hz, 1H, Cpr-CH), 1.37 (d, J=4.8 Hz, 1H, Cpr-CH), 1.33 (s, 3H, Me), $1.18(\mathrm{t}, J=7.1 \mathrm{~Hz}, 3 \mathrm{H},-\mathrm{CH} 2 \mathrm{CH} 3), 1.12$ (s, 3H, Me). ${ }^{13} \mathrm{C}-\mathrm{NMR}(101 \mathrm{MHz}, \mathrm{MeOD}) \delta 171.4,168.3$, 143.4, 139.8, 128.2, 120.67, 62.8, 42.8, 31.7, 26.5, 23.3, 20.4, 14.5. HRMS-ESI Calcd. for $\mathrm{C}_{15} \mathrm{H}_{21} \mathrm{~N}_{2} \mathrm{O}_{5} \mathrm{~S}$ $[\mathrm{M}+\mathrm{H}]^{+}:$341.1171; Found: 341.1433 .

\subsubsection{2,2-Dimethyl-1-(4-sulfamoylphenylcarbamoyl)cyclopropanecarboxylic Acid 11}

$1 \mathrm{~mol} / \mathrm{L}$ sodium hydroxide $(12 \mathrm{~mL})$ was added dropwise to a solution of compound $\mathbf{1 0}(3.4 \mathrm{~g})$ in ethanol $(20 \mathrm{~mL})$. The resulting mixture was stirred at room temperature for $18 \mathrm{~h}$. EtOH was removed under reduced pressure and the mixture was extracted with ethyl acetate $(10 \mathrm{~mL} \times 2)$. The remaining aqueous layer was acidified to $\mathrm{pH} 2$ by $3 \mathrm{~mol} / \mathrm{L} \mathrm{HCl}$, extracted with ethyl acetate $(10 \mathrm{~mL} \times 2)$. The organic layer was concentrated to give a pale yellow oil and further crystallized by ethyl ether to give compound 11 as a white solid. Yield: $88 \%$; mp: $180-183{ }^{\circ} \mathrm{C}$; ${ }^{1} \mathrm{H}-\mathrm{NMR}$ (400 MHz, DMSO) $\delta 12.87$ (s, 1H), 10.41 (s, 1H), 7.95-7.62 (m, 4H), $7.24(\mathrm{~s}, 2 \mathrm{H}), 1.35(\mathrm{~d}, J=4.5 \mathrm{~Hz}, 1 \mathrm{H}), 1.33(\mathrm{~s}, 3 \mathrm{H}), 1.31(\mathrm{~d}, J=4.5 \mathrm{~Hz}, 1 \mathrm{H})$, $1.10(\mathrm{~s}, 3 \mathrm{H}) .{ }^{13} \mathrm{C}-\mathrm{NMR}(101 \mathrm{MHz}, \mathrm{MeOD}) \delta 173.3,168.8,143.4,139.7,128.2,120.6,42.5,31.7,26.3$, 23.0, 20.6. HRMS-ESI Calcd. for $\mathrm{C}_{13} \mathrm{H}_{16} \mathrm{~N}_{2} \mathrm{NaO}_{5} \mathrm{~S}[\mathrm{M}+\mathrm{Na}]^{+}$: 335.0672; Found: 335.0826.

\subsubsection{General Produce for the Synthesis of Compounds 12a-n}

Compound $11(0.62 \mathrm{~g})$ and HOBt $(0.27 \mathrm{~g})$ were dissolved in anhydrous tetrahydrofuran $(10 \mathrm{~mL})$ and was transferred to a stirred solution of EDCI $(0.4 \mathrm{~g})$ in dicolormethane $(10 \mathrm{~mL})$. After $0.5 \mathrm{~h}$, a suitable amine $(2 \mathrm{mmol})$ in tetrahydrofuran $(5 \mathrm{~mL})$ was added, the reaction was monitored by TLC analysis and completed in 12-24 h. The solvents were evaporated under vacuum to give a yellow oil, which was chromatographed (Petroleum ether-EtOAc system) to give compounds $\mathbf{1 2 a}-\mathbf{n}$ as white solids.

N-tert-Butyl-2,2-dimethyl-N-(4-sulfamoylphenyl)cyclopropane-1,1-dicarboxamide (12a): Yield: 70\%; mp: $212-215{ }^{\circ} \mathrm{C} ;{ }^{1} \mathrm{H}-\mathrm{NMR}$ (400 MHz, DMSO) $\delta 10.33$ (s, 1H, CONH), 7.76 (s, 4H, ArH), 7.59 (s, 1H, $\mathrm{NH}), 7.27$ (s, 2H, $\left.\mathrm{SO}_{2} \mathrm{NH}_{2}\right), 1.47$ (d, $\left.J=5.5 \mathrm{~Hz}, 1 \mathrm{H}, \mathrm{Cpr}-\mathrm{CH}\right), 1.40$ (d, $\left.J=5.3 \mathrm{~Hz}, 1 \mathrm{H}, \mathrm{Cpr}-\mathrm{CH}\right), 1.27$ (s, 9H, Me), 1.10 (s, 3H, Me), 1.06 (s, 3H, Me ). ${ }^{13} \mathrm{C}-\mathrm{NMR}(101 \mathrm{MHz}, \mathrm{MeOD}) \delta 169.8,169.7,142.8$, 
140.2, 128.2, 120.8, 52.7, 44.6, 28.8, 28.0, 23.3, 21.8, 21.6. MS-ESI [M + H] 368.2. HRMS-ESI Calcd. for $\mathrm{C}_{17} \mathrm{H}_{25} \mathrm{~N}_{3} \mathrm{NaO}_{4} \mathrm{~S}[\mathrm{M}+\mathrm{Na}]^{+}: 390.1463$; Found: 390.1567 .

N,N-Diethyl-2,2-dimethyl-N-(4-sulfamoylphenyl)cyclopropane-1,1-dicarboxamide (12b): Yield: 75\%; mp: $156-158{ }^{\circ} \mathrm{C} ;{ }^{1} \mathrm{H}-\mathrm{NMR}(400 \mathrm{MHz}, \mathrm{DMSO}) \delta 9.83$ (s, 1H, CONH), 7.79 (d, J=8.9 Hz, 2H, ArH), $7.73(\mathrm{~d}, J=8.9 \mathrm{~Hz}, 2 \mathrm{H}, \mathrm{ArH}), 7.25$ (s, 2H, SO $\left.\mathrm{NH}_{2}\right), 3.32$ (m, 4H, -CH2CH3), 1.37 (d, J=4.9 Hz, 1H, Cpr-CH), 1.16 (s, 3H, Me), 1.14 (d, J=5.0 Hz, 1H, Cpr-CH), 1.10 (s, 3H, Me), 1.05 (t, J=6.9 Hz, 3H, $\mathrm{Me}), 1.00(\mathrm{t}, J=7.0 \mathrm{~Hz}, 3 \mathrm{H}, \mathrm{Me}){ }^{13} \mathrm{C}-\mathrm{NMR}(101 \mathrm{MHz}, \mathrm{MeOD}) \delta 170.5,168.1,143.0,140.1,128.4$, 128.3, 120.6, 43.8, 43.1, 41.2, 28.0, 25.4, 24.1, 21.5, 14.1, 12.8. MS-ESI [M + H] $]^{+}: 368.2$. HRMS-ESI Calcd. for $\mathrm{C}_{17} \mathrm{H}_{25} \mathrm{~N}_{3} \mathrm{NaO}_{4} \mathrm{~S}\left[\mathrm{M}+\mathrm{Na}^{+}\right.$: 390.1463; Found: 390.1561 .

2,2-Dimethyl-N-(4-sulfamoylphenyl)cyclopropane-1,1-dicarboxamide (12c): Yield: 60\%; mp: 197-200 ${ }^{\circ} \mathrm{C}$; ${ }^{1} \mathrm{H}-\mathrm{NMR}(400 \mathrm{MHz}, \mathrm{DMSO}) \delta 10.60$ (s, 1H, CONH), 7.76 (s, 4H, ArH), 7.54 (d, J=5.2 Hz, 2H, NH ), 7.26 (s, 2H, SO $\mathrm{NH}_{2}$ ), 1.46 (d, $\left.J=5.5 \mathrm{~Hz}, 1 \mathrm{H}, \mathrm{Cpr}-\mathrm{CH}\right), 1.44$ (d, $\left.J=5.5 \mathrm{~Hz}, 1 \mathrm{H}, \mathrm{Cpr}-\mathrm{CH}\right), 1.15$ (s, 3H, Me), 1.08 (s, 3H, Me). ${ }^{13} \mathrm{C}-\mathrm{NMR}(101 \mathrm{MHz}, \mathrm{MeOD}) \delta$ 173.7, 169.0, 142.9, 140.0, 128.3, 120.8, 43.6, 28.7, 24.3, 23.4, 21.7, 21.6. MS-ESI $[\mathrm{M}+\mathrm{H}]^{+}:$312.1. HRMS-ESI Calcd. for $\mathrm{C}_{13} \mathrm{H}_{17} \mathrm{~N}_{3} \mathrm{NaO}_{4} \mathrm{~S}[\mathrm{M}+\mathrm{Na}]^{+}$: 334.0837; Found: 334.1000 .

N,2,2-Trimethyl-N-(4-sulfamoylphenyl)cyclopropane-1,1-dicarboxamide (12d): Yield: 80\%; mp: 217-220 ${ }^{\circ} \mathrm{C}$; ${ }^{1} \mathrm{H}-\mathrm{NMR}$ (400 MHz, DMSO) $\delta 10.56$ (s, 1H, CONH), 8.02 (d, J=4.6 Hz, 1H, NH), 7.76 (s, 4H, ArH), 7.27 (s, 2H, $\left.\mathrm{SO}_{2} \mathrm{NH}_{2}\right), 2.65$ (d, J=4.6 Hz, 3H, Me), 1.44 (s, 2H, Cpr-CH), 1.08 (s, 6H, Me). ${ }^{13} \mathrm{C}-\mathrm{NMR}$ (101 MHz, MeOD) $\delta 171.8,168.6,142.9,134.0,128.3,120.6,43.9,28.6,26.7,22.9,21.9$, 21.3. MS-ESI $[\mathrm{M}+\mathrm{H}]^{+}:$326.1. HRMS-ESI Calcd. for $\mathrm{C}_{14} \mathrm{H}_{19} \mathrm{~N}_{3} \mathrm{NaO}_{4} \mathrm{~S}[\mathrm{M}+\mathrm{Na}]^{+}: 348.0994$; Found: 348.1202.

2,2-Dimethyl-N-propyl-N-(4-sulfamoylphenyl)cyclopropane-1,1-dicarboxamide (12e): Yield: 70\%; mp: 180-183 ${ }^{\circ} \mathrm{C}$; ${ }^{1} \mathrm{H}-\mathrm{NMR}$ (400 MHz, DMSO) $\delta 10.53$ (s, 1H, CONH), 8.09 (t, $\left.J=5.7 \mathrm{~Hz}, 1 \mathrm{H}, \mathrm{NH}\right), 7.76$ (s, 4H, ArH), 7.27 (s, 2H, $\left.\mathrm{SO}_{2} \mathrm{NH}_{2}\right), 3.19-2.95$ (m, 2H, $\left.\mathrm{CH}_{2}\right), 1.47(\mathrm{~d}, J=7.2 \mathrm{~Hz}, 1 \mathrm{H}, \mathrm{Cpr}-\mathrm{CH}), 1.45$ (m, 2H, CH ), 1.42 (d, J=7.2 Hz, 1H, Cpr-CH), 1.09 (s, 3H, Me), 1.08 (s, 3H, Me), 0.83 (t, J= 7.4 Hz, $3 \mathrm{H}, \mathrm{Me}) .{ }^{13} \mathrm{C}-\mathrm{NMR}(101 \mathrm{MHz}, \mathrm{MeOD}) \delta 176.0,174.2,142.8,140.1,128.2,121.4,59.0,42.5,40.9,23.5$, 19.5, 14.6, 11.8. MS-ESI $[\mathrm{M}+\mathrm{H}]^{+}: 354.1$. HRMS-ESI Calcd. for $\mathrm{C}_{16} \mathrm{H}_{23} \mathrm{~N}_{3} \mathrm{NaO}_{4} \mathrm{~S}[\mathrm{M}+\mathrm{Na}]^{+}: 376.1307$; Found: 376.1458.

N-(4-Bromophenyl)-2,2-dimethyl-N-(4-sulfamoylpheny-l)cyclopropane-1,1-dicarboxamide (12f): Yield: 50\%; mp: 199-201 ${ }^{\circ} \mathrm{C} ;{ }^{1} \mathrm{H}-\mathrm{NMR}$ (400 MHz, DMSO) $\delta 10.24$ (s, 1H, CONH), 10.05 (s, 1H, NH), 7.78 (q, $J=9.1 \mathrm{~Hz}, 4 \mathrm{H}, \mathrm{ArH}), 7.61(\mathrm{~d}, J=8.9 \mathrm{~Hz}, 2 \mathrm{H}, \operatorname{ArH}), 7.52$ (t, $J=8.7 \mathrm{~Hz}, 2 \mathrm{H}, \operatorname{ArH}), 7.28(\mathrm{~s}, 2 \mathrm{H}$, $\mathrm{SO}_{2} \mathrm{NH}_{2}$ ), 1.59 (s, 2H, Cpr-CH), 1.17 (s, 6H, Me). ${ }^{13} \mathrm{C}-\mathrm{NMR}$ (101 MHz, DMSO) $\delta 166.7,141.1,139.0$, $137.5,131.5,126.6,122.2,119.6,115.7,43.4,27.0,22.8,21.4,21.2$. MS-ESI $[\mathrm{M}+\mathrm{H}]^{+}:$467.0. HRMS-ESI Calcd. for $\mathrm{C}_{19} \mathrm{H}_{20} \mathrm{BrN}_{3} \mathrm{NaO}_{4} \mathrm{~S}[\mathrm{M}+\mathrm{Na}]^{+}:$488.0256, 490.0235; Found: 488.0389, 490.0376.

2,2-Dimethyl-1-(morpholine-4-carbonyl)-N-(4-sulfamoylphenyl)cyclopropanecarboxamide (12g): Yield: 65\%; mp: 170-173 ${ }^{\circ} \mathrm{C},{ }^{1} \mathrm{H}-\mathrm{NMR}$ (400 MHz, DMSO) $\delta 9.93$ (s, 1H, CONH), 7.78 (m, 4H, ArH), 7.27 (s, 2H, $\left.\mathrm{SO}_{2} \mathrm{NH}_{2}\right), 3.53\left(\mathrm{~m}, 8 \mathrm{H}, \mathrm{CH}_{2}\right), 1.39$ (d, $\left.J=5.1 \mathrm{~Hz}, 1 \mathrm{H}, \mathrm{Cpr}-\mathrm{CH}\right), 1.16$ (s, 3H, Me), 1.14 (d, J=5.1 Hz, 1H, $\mathrm{Cpr}-\mathrm{CH}), 1.12$ (s, 3H, Me). ${ }^{13} \mathrm{C}-\mathrm{NMR}(101 \mathrm{MHz}, \mathrm{MeOD}) \delta$ 169.6, 168.1, 143.0, 140.2, 128.2, 127.1, 
120.8, 66.8, 43.0, 27.9, 25.4, 23.9, 21.7, 15.5. MS-ESI $[\mathrm{M}+\mathrm{H}]^{+}:$382.1. HRMS-ESI Calcd. for $\mathrm{C}_{17} \mathrm{H}_{23} \mathrm{~N}_{3} \mathrm{NaO}_{5} \mathrm{~S}[\mathrm{M}+\mathrm{Na}]^{+}$: 404.1256; Found: 404.1285.

$N$-(4-Fluorophenyl)-2,2-dimethyl-N-(4-sulfamoylphenyl)cyclopropane-1,1-dicarboxamide (12h): Yield: 60\%; mp: 200-203 ${ }^{\circ} \mathrm{C} ;{ }^{1} \mathrm{H}-\mathrm{NMR}$ (400 MHz, DMSO) $\delta 10.27$ (s, 1H, CONH), 9.99 (s, 1H, NH), 7.88-7.70 (m, 4H, ArH), 7.70-7.55 (m, 2H, ArH), 7.28 (s, 2H, $\left.\mathrm{SO}_{2} \mathrm{NH}_{2}\right), 7.17$ (dd, J=12.3, $5.5 \mathrm{~Hz}, 2 \mathrm{H}, \mathrm{ArH}$ ), 1.59 (s, 2H, Cpr-CH), 1.17 (s, 3H, Me), 1.15 (s, 3H, Me). ${ }^{13} \mathrm{C}-\mathrm{NMR}$ (101 MHz, MeOD) $\delta$ 169.2, 169.0, 162.3, 159.9, 142.7, 140.2, 135.2, 128.2, 124.0, 124.0, 121.0, 116.5, 116.3, 44.7, 29.2, 23.5, 22.0, 21.6. MS-ESI $[\mathrm{M}+\mathrm{H}]^{+}:$406.1. HRMS-ESI Calcd. for $\mathrm{C}_{17} \mathrm{H}_{23} \mathrm{~N}_{3} \mathrm{NaO}_{5} \mathrm{~S}$ [M + Na] $]^{+}$: 404.1256; Found: 404.1285.

2,2-Dimethyl-N-(4-sulfamoylphenyl)-N-p-tolylcyclopropane-1,1-dicarboxamide (12i): Yield: 70\%; mp: 134-136 ${ }^{\circ} \mathrm{C} ;{ }^{1} \mathrm{H}-\mathrm{NMR}(400 \mathrm{MHz}, \mathrm{DMSO}) \delta 10.31$ (s, 1H, CONH), 9.85 (s, 1H, NH), 7.78 (q, J=9.0 Hz, 4H, ArH), 7.49 (d, $J=8.3 \mathrm{~Hz}, 2 \mathrm{H}, \mathrm{ArH}), 7.27$ (s, 2H, SO $2 \mathrm{NH}_{2}$ ), 7.13 (d, $\left.J=8.2 \mathrm{~Hz}, 2 \mathrm{H}, \mathrm{ArH}\right), 2.26$ (s, 3H, Me), $1.60(\mathrm{~d}, J=5.7 \mathrm{~Hz}, 1 \mathrm{H}, \mathrm{Cpr}-\mathrm{CH}), 1.58$ (d, $J=5.7 \mathrm{~Hz}, 1 \mathrm{H}, \mathrm{Cpr}-\mathrm{CH}), 1.16$ (s, 3H, Me), 1.14 (s, 3H, Me) ${ }^{13} \mathrm{C}-\mathrm{NMR}$ (101 MHz, MeOD) $\delta 169.1,169.0,142.7,140.2,137.9,130.7,129.9,128.2,123.2,121.0$, 44.8, 29.3, 23.6, 21.9, 21.7. MS-ESI [M + H] $]^{+}: 402.1$. HRMS-ESI Calcd. for $\mathrm{C}_{20} \mathrm{H}_{23} \mathrm{~N}_{3} \mathrm{NaO}_{4} \mathrm{~S}[\mathrm{M}+\mathrm{Na}]^{+}$: 424.1307; Found: 424.1422.

2,2-Dimethyl-1-(piperidine-1-carbonyl)-N-(4-sulfamoylpenyl)cyclopropanecarboxamide (12j): Yield: 50\%; mp: 207-209 ${ }^{\circ} \mathrm{C}$; ${ }^{1} \mathrm{H}-\mathrm{NMR}(400 \mathrm{MHz}, \mathrm{DMSO}) \delta 9.79$ (s, 1H, CONH), 7.76 (d, 8.9 Hz, 2H, ArH), 7.56 (d, $8.9 \mathrm{~Hz}, 2 \mathrm{H}, \mathrm{ArH}), 7.25$ (s, 2H, SO $\left.\mathrm{SH}_{2}\right), 3.75\left(\mathrm{~s}, 1 \mathrm{H}, \mathrm{CH}_{2}\right), 3.51\left(\mathrm{~s}, 2 \mathrm{H}, \mathrm{CH}_{2}\right), 3.38\left(\mathrm{~s}, 1 \mathrm{H}, \mathrm{CH}_{2}\right)$, $1.44\left(\mathrm{~m}, 6 \mathrm{H}, \mathrm{CH}_{2}\right), 1.40$ (d, J=4.9 Hz, 1H, Cpr-CH), 1.15 (s, 3H, Me), 1.11 (s, 3H, Me), 1.09 (d, J=5.0 Hz, $1 \mathrm{H}, \mathrm{Cpr}-\mathrm{CH}) .{ }^{13} \mathrm{C}-\mathrm{NMR}(101 \mathrm{MHz}, \mathrm{MeOD}) \delta 169.5,168.1,143.0,140.1,128.2,120.6,43.0,30.7,28.2$, 27.6, 26.8, 25.6, 25.3, 24.0, 21.5. MS-ESI [M + H] $]^{+}: 380.1$. HRMS-ESI Calcd. for $\mathrm{C}_{18} \mathrm{H}_{25} \mathrm{~N}_{3} \mathrm{NaO}_{4} \mathrm{~S}$ $[\mathrm{M}+\mathrm{Na}]^{+}: 402.1463$; Found: 402.1567 .

N-Butyl-2,2-dimethyl-N-(4-sulfamoylphenyl)cyclopropane-1,1-dicarboxamide (12k): Yield: 57\%; mp: 170-172 ${ }^{\circ} \mathrm{C}$; ${ }^{1} \mathrm{H}-\mathrm{NMR}(400 \mathrm{MHz}, \mathrm{DMSO}) \delta 10.53$ (s, 1H, CONH), 8.08 (t, $\left.J=5.6 \mathrm{~Hz}, 1 \mathrm{H}, \mathrm{NH}\right), 7.75$ (s, 4H, ArH), 7.26 (s, 2H, SO $\left.\mathrm{NH}_{2}\right), 3.25-2.98$ (m, 2H, $\left.\mathrm{CH}_{2}\right), 1.45$ (s, 2H, Cpr-CH), 1.40 (m, 2H, $\left.\mathrm{CH}_{2}\right)$, $1.26\left(\mathrm{~m}, 2 \mathrm{H}, \mathrm{CH}_{2}\right), 1.09$ (s, 3H, Me), 1.08 (s, 3H, Me), 0.86 (t, J=7.3 Hz, 3H, Me). ${ }^{13} \mathrm{C}-\mathrm{NMR}(101 \mathrm{MHz}$, MeOD) $\delta 171.1,168.8,142.8,140.0,128.3,120.6$, 44.0, 40.7, 32.5, 28.4, 23.0, 22.0, 21.4, 21.2, 14.1. MS-ESI $[\mathrm{M}+\mathrm{H}]^{+}:$368.1. HRMS-ESI Calcd. for $\mathrm{C}_{17} \mathrm{H}_{25} \mathrm{~N}_{3} \mathrm{NaO}_{4} \mathrm{~S}[\mathrm{M}+\mathrm{Na}]^{+}:$390.1463; Found: 390.1566.

2,2-Dimethyl-1-(pyrrolidine-1-carbonyl)-N-(4-sulfamoylphenyl)cyclopropanecarboxamide (121): Yield: 39\%; mp: $225-227{ }^{\circ} \mathrm{C}$; ${ }^{1} \mathrm{H}-\mathrm{NMR}(400 \mathrm{MHz}, \mathrm{DMSO}) \delta 9.88$ (s, 1H, CONH), 7.76 (q, $J=9.0 \mathrm{~Hz}, 4 \mathrm{H}, \mathrm{ArH}$ ), $7.27\left(\mathrm{~s}, 2 \mathrm{H}, \mathrm{SO}_{2} \mathrm{NH}_{2}\right), 3.53\left(\mathrm{~m}, 2 \mathrm{H}, \mathrm{CH}_{2}\right), 3.35\left(\mathrm{~m}, 2 \mathrm{H}, \mathrm{CH}_{2}\right), 1.92-1.78\left(\mathrm{~m}, 2 \mathrm{H}, \mathrm{CH}_{2}\right), 1.78-1.64(\mathrm{~m}$, 2H, $\left.\mathrm{CH}_{2}\right), 1.39$ (d, $\left.J=5.0 \mathrm{~Hz}, 1 \mathrm{H}, \mathrm{Cpr}-\mathrm{CH}\right), 1.22$ (d, $\left.J=5.0 \mathrm{~Hz}, 1 \mathrm{H}, \mathrm{Cpr}-\mathrm{CH}\right), 1.15$ (s, 3H, Me), 1.12 (s, 3H, Me). MS-ESI $[\mathrm{M}+\mathrm{H}]^{+}:$366.1. HRMS-ESI Calcd. for $\mathrm{C}_{17} \mathrm{H}_{23} \mathrm{~N}_{3} \mathrm{NaO}_{4} \mathrm{~S}[\mathrm{M}+\mathrm{Na}]^{+}: 388.1307$; Found: 388.1356.

N-(4-Chlorophenyl)-2,2-dimethyl-N-(4-sulfamoylphenyl)cyclopropane-1,1-dicarboxamide (12m): Yield: 70\%; mp: 210-213 ${ }^{\circ} \mathrm{C} ;{ }^{1} \mathrm{H}-\mathrm{NMR}$ (400 MHz, DMSO) $\delta 10.26$ (s, 1H, CONH), 10.07 (s, 1H, NH), 7.78 (m, 4H, ArH), 7.67 (d, $J=8.8 \mathrm{~Hz}, 2 \mathrm{H}, \mathrm{ArH}), 7.38$ (d, $J=8.8 \mathrm{~Hz}, 2 \mathrm{H}, \mathrm{ArH}), 7.28\left(\mathrm{~s}, 2 \mathrm{H}, \mathrm{SO}_{2} \mathrm{NH}_{2}\right), 1.59$ 
(s, 2H, Cpr-CH), 1.16 (d, $J=3.0 \mathrm{~Hz}, 6 \mathrm{H}, \mathrm{Me}) .{ }^{13} \mathrm{C}-\mathrm{NMR}$ (101 MHz, MeOD) $\delta 169.1,169.0,142.7$, 140.2, 137.9, 130.7, 129.9, 128.2, 123.2, 121.0, 44.8, 29.3, 23.6, 21.9, 21.7. MS-ESI [M + H] $]^{+}$422.0. HRMS-ESI Calcd. for $\mathrm{C}_{19} \mathrm{H}_{20} \mathrm{ClN}_{3} \mathrm{NaO}_{4} \mathrm{~S}[\mathrm{M}+\mathrm{Na}]^{+}$: 444.0761 ; Found: 444.0884.

N-Allyl-2,2-dimethyl-N-(4-sulfamoylphenyl)cyclopropane-1,1-dicarboxamide (12n): Yield: 80\%; mp: 179-181 ${ }^{\circ} \mathrm{C}$; ${ }^{1} \mathrm{H}-\mathrm{NMR}(400 \mathrm{MHz}, \mathrm{DMSO}) \delta 10.46$ (s, $\left.1 \mathrm{H}, \mathrm{CONH}\right), 8.23$ (t, $\left.J=5.7 \mathrm{~Hz}, 1 \mathrm{H}, \mathrm{NH}\right), 7.76$ (s, 4H, ArH), 7.27 (s, 2H, SO $\left.2 \mathrm{NH}_{2}\right), 5.92-5.67$ (m, 1H, CH), 5.29-4.96 (m, 3H, Me), 3.77 (m, 3H, Me), 1.49 (d, $J=5.5 \mathrm{~Hz}, 1 \mathrm{H}, \mathrm{Cpr}-\mathrm{CH}), 1.45$ (d, $J=5.5 \mathrm{~Hz}, 1 \mathrm{H}, \mathrm{Cpr}-\mathrm{CH}), 1.10$ (s, 3H, Me), 1.09 (s, 3H, Me). ${ }^{13} \mathrm{C}-\mathrm{NMR}(101 \mathrm{MHz}, \mathrm{MeOD}) \delta 170.9,168.8,142.8,140.0,135.2,128.3,120.7,116.6,44.0,43.2,28.5$, 23.1, 21.9, 21.5. MS-ESI $[\mathrm{M}+\mathrm{H}]^{+}:$352.1. HRMS-ESI Calcd. for $\mathrm{C}_{16} \mathrm{H}_{21} \mathrm{~N}_{3} \mathrm{NaO}_{4} \mathrm{~S}[\mathrm{M}+\mathrm{Na}]^{+}: 374.1150$; Found: 374.1182.

3.2.4. Ethyl 2-Propyl-2-(4-sulfamoylphenylcarbamoyl)pentanoate $\mathbf{1 6}$

Ethyl 2-propyl-2-(4-sulfamoylphenylcarbamoyl)pentanoate (16): Yield: 50\%; mp: $112-115{ }^{\circ} \mathrm{C} ;{ }^{1} \mathrm{H}-\mathrm{NMR}$ (400 MHz, DMSO) $\delta 9.82(\mathrm{~s}, 1 \mathrm{H}, \mathrm{CONH}), 7.85-7.67$ (m, 4H, ArH), 7.27 (s, 2H, SO $\left.2 \mathrm{NH}_{2}\right), 4.15$ (q, $\left.J=7.1 \mathrm{~Hz}, 2 \mathrm{H}, \mathrm{CH}_{2}\right), 1.93-1.79\left(\mathrm{~m}, 4 \mathrm{H}, \mathrm{CH}_{2}\right), 1.18\left(\mathrm{~m}, 4 \mathrm{H}, \mathrm{CH}_{2}\right), 1.17\left(\mathrm{t}, J=7.1 \mathrm{~Hz}, 3 \mathrm{H}, \mathrm{CH}_{2} \mathrm{CH}_{3}\right)$, $0.89(\mathrm{t}, J=7.2 \mathrm{~Hz}, 6 \mathrm{H}, \mathrm{Me}) .{ }^{13} \mathrm{C}-\mathrm{NMR}(101 \mathrm{MHz}, \mathrm{MeOD}) \delta 175.2,172.4,142.8,140.2,128.2,121.6$, 121.5, 62.7, 60.1, 38.6, 19.2, 14.7, 14.5. HRMS-ESI Calcd. for $\mathrm{C}_{17} \mathrm{H}_{27} \mathrm{~N}_{2} \mathrm{O} 5 \mathrm{~S}[\mathrm{M}+\mathrm{H}]^{+}: 371.1641$; Found: 371.1610 .

\subsubsection{2-Propyl-2-(4-sulfamoylphenylcarbamoyl)pentanoic Acid 17}

2-Propyl-2-(4-sulfamoylphenylcarbamoyl)pentanoic acid (17): Yield: 50\%; mp: 78-80 ${ }^{\circ} \mathrm{C}$; ${ }^{1} \mathrm{H}-\mathrm{NMR}$ (400 MHz, DMSO) $\delta 9.96$ (s, 1H, CONH), 7.80 (d, $J=9.0 \mathrm{~Hz}, 2 \mathrm{H}, \mathrm{ArH}), 7.75$ (d, J=9.0 Hz, 2H, ArH), 7.27 (s, 2H, SO $\left.2 \mathrm{NH}_{2}\right), 1.96-1.75\left(\mathrm{~m}, 4 \mathrm{H}, \mathrm{CH}_{2}\right), 1.29-1.05\left(\mathrm{~m}, 4 \mathrm{H}, \mathrm{CH}_{2}\right), 0.88$ (t, $\left.J=7.2 \mathrm{~Hz}, 6 \mathrm{H}, \mathrm{Me}\right)$. ${ }^{13} \mathrm{C}-\mathrm{NMR}$ (101 MHz, MeOD) $\delta$ 177.9, 173.1, 142.6, 140.2, 128.3, 121.4, 59.7, 40.0, 19.5, 14.6. HRMS-ESI Calcd. for $\mathrm{C}_{15} \mathrm{H}_{23} \mathrm{~N}_{2} \mathrm{O} 5 \mathrm{~S}[\mathrm{M}+\mathrm{H}]^{+}$: 343.1322; Found: 343.1296 .

3.2.6. General Produce for the Synthesis of Compounds 18a-c

The synthesis of compounds $\mathbf{1 8 a}-\mathbf{c}$ was similar to the synthesis of compounds $\mathbf{1 2} \mathbf{a}-\mathbf{n}$.

$N^{1}$-Allyl-2,2-dipropyl- $N^{3}$-(4-sulfamoylphenyl)malonamide (18a): Yield: 60\%; mp: $189-192{ }^{\circ} \mathrm{C} ;{ }^{1} \mathrm{H}-\mathrm{NMR}$ (400 MHz, DMSO) $\delta 10.86$ (s, 1H, CONH), 8.32 (t, $J=5.7 \mathrm{~Hz}, 1 \mathrm{H}, \mathrm{NH}), 7.85-7.77$ (m, 2H, ArH), 7.77-7.73 (m, 2H, ArH), 7.27 (s, 2H, SO $\left.2 \mathrm{NH}_{2}\right), 5.90-5.72(\mathrm{~m}, 1 \mathrm{H}, \mathrm{CH}), 5.19-4.99\left(\mathrm{~m}, 2 \mathrm{H}, \mathrm{CH}_{2}\right), 3.78(\mathrm{t}, J=5.3 \mathrm{~Hz}$, $2 \mathrm{H}, \mathrm{CH}=\mathrm{CH} 2), 1.98-1.79\left(\mathrm{~m}, 4 \mathrm{H}, \mathrm{CH}_{2}\right), 1.18-1.04\left(\mathrm{~m}, 4 \mathrm{H}, \mathrm{CH}_{2}\right), 0.85$ (t, $\left.J=7.3 \mathrm{~Hz}, 6 \mathrm{H}, \mathrm{Me}\right) .{ }^{13} \mathrm{C}-\mathrm{NMR}$ (101 MHz, MeOD) $\delta 175.9,174.2,142.8,140.1,128.2,121.3,58.9,40.9,40.4,32.5,21.2,19.5,14.6$, 14.2. MS-ESI $[\mathrm{M}+\mathrm{H}]^{+}:$382.2. HRMS-ESI Calcd. for $\mathrm{C}_{18} \mathrm{H}_{28} \mathrm{~N}_{3} \mathrm{O}_{4} \mathrm{~S}[\mathrm{M}+\mathrm{H}]^{+}:$382.1801; Found:382.1769.

2,2-Dipropyl-N ${ }^{1}$-(4-sulfamoylphenyl)malonamide (18b): Yield: $60 \%$; mp: 202-205 ${ }^{\circ} \mathrm{C}$; ${ }^{1} \mathrm{H}-\mathrm{NMR}(400 \mathrm{MHz}$, DMSO) $\delta 11.15$ (s, 1H, CONH), 7.85-7.70 (m, 4H, ArH), 7.65 (s, 1H, NH), 7.50 (s, 1H, NH), 7.27 (s, 2H, $\left.\mathrm{SO}_{2} \mathrm{NH}_{2}\right), 1.93-1.65$ (m, 4H, CH 2$), 1.21-1.03$ (m, 4H, CH$), 0.84$ (m, 6H, Me). ${ }^{13} \mathrm{C}-\mathrm{NMR}(101 \mathrm{MHz}$, 
MeOD) $\delta 179.2,173.9,142.8,140.1,128.2,121.3,59.0,41.0,19.5,14.6$. MS-ESI $[\mathrm{M}+\mathrm{H}]^{+}: 342.1$. HRMS-ESI Calcd. for $\mathrm{C}_{15} \mathrm{H}_{24} \mathrm{~N}_{3} \mathrm{O}_{4} \mathrm{~S}[\mathrm{M}+\mathrm{H}]^{+}: 342.1488$; Found: 342.1460 .

N1,2,2-Tripropyl- $N^{3}$-(4-sulfamoylphenyl)malonamide (18c): Yield: 55\%; mp: $189-192{ }^{\circ} \mathrm{C}$; ${ }^{1} \mathrm{H}-\mathrm{NMR}$ (400 MHz, DMSO) $\delta 11.14$ (s, 1H, CONH), 8.18 (t, $J=5.5 \mathrm{~Hz}, 1 \mathrm{H}, \mathrm{NH}), 7.95-7.71(\mathrm{~m}, 4 \mathrm{H}, \mathrm{ArH}), 7.32$ (s, $\left.2 \mathrm{H}, \mathrm{SO}_{2} \mathrm{NH}_{2}\right), 3.20\left(\mathrm{~m}, 2 \mathrm{H}, \mathrm{CH}_{2}\right), 2.02-1.80(\mathrm{~m}, 4 \mathrm{H}), 1.55-1.39\left(\mathrm{~m}, 2 \mathrm{H}, \mathrm{CH}_{2}\right), 1.31\left(\mathrm{~m}, 4 \mathrm{H}, \mathrm{CH}_{2}\right)$, 1.21-1.08 (m, 4H, CH2), 0.91 (m, 9H, Me). ${ }^{13} \mathrm{C}-\mathrm{NMR}$ (101 MHz, MeOD) $\delta 175.9,174.1,142.8,140.1$, 135.5, 128.2, 121.4, 116.4, 59.1, 42.9, 40.7, 19.5, 14.6. MS-ESI $[\mathrm{M}+\mathrm{H}]^{+}:$384.2. HRMS-ESI Calcd. for $\mathrm{C}_{18} \mathrm{H}_{28} \mathrm{~N}_{3} \mathrm{O}_{4} \mathrm{~S}[\mathrm{M}+\mathrm{H}]^{+}: 382.1801$; Found: 382.1786.

\subsection{Pharmacology}

\subsubsection{Preparation of the Compounds for Testing}

All the tested compounds were suspended in 5\% carboxymethyl cellulose sodium in sterilizedphysiological saline solution. The pentylenetetrazol was prepared by dissolution of pentylenetetrazol in sterilized physiological saline to make a $0.8 \%$ solution.

\subsubsection{MES Test}

Kunming mice (18-22 g) purchased from Wuhan University Laboratory Animal Center were used in the MES test. After $0.5 \mathrm{~h}$ and $4 \mathrm{~h}$ of intraperitoneal (i.p.) administration of drugs at doses of $300 \mathrm{mg} / \mathrm{kg}$, $100 \mathrm{mg} / \mathrm{kg}$ and $30 \mathrm{mg} / \mathrm{kg}$, the mice were stimulated by an electrical stimulus $(50 \mathrm{~mA}, 60 \mathrm{~Hz}, 0.2 \mathrm{~s})$ through ear electrodes. Because the aim in this work was to find more effective and safer anticonvulsant drugs, the high, middle and low doses of drugs were chosen according to the effective dose of the drugs used clinically and reported previously by our group $[21,22,24,25]$. The procedure may cause the mice immediate hindlimb tonic extension. Protection against seizure was defined as the absence of hindlimb tonic extension. The duration of tonic seizures was analyzed over 5 min [35].

\subsection{3. scPTZ Test}

After $0.5 \mathrm{~h}$ and $4 \mathrm{~h}$ of i.p. administration of drugs, the pentylenetetrazol solution was injected subcutaneously. Protection against pentylenetetrazol induced seizure was defined as the abolition of a threshold. All animals were observed for $30 \mathrm{~min}$ [36].

\subsubsection{Neurotoxicity Screening}

The neurotoxicity of compounds was measured according to standardized rotorod test. Trained mice were placed on an accelerating rotarod (diameter $3.2 \mathrm{~cm}$ ) rotating at $10 \mathrm{rpm}$ after drug administration. Neurotoxicity was defined as the inability of the mice to keep balance on the rotarod fpr at least $1 \mathrm{~min}$

\subsubsection{Calculation of $\mathrm{Clog} P$}

ClogP was calculated by using ChemDraw-Ultra software (Version 6.0.1; PerkinElmer Informatics, Waltham, MA, USA). 


\subsubsection{Quntification Studies}

For the determination of the median effective dose (ED50), groups of 10 mice were given a range of i.p. doses $(160 \mathrm{mg} / \mathrm{kg}, 80 \mathrm{mg} / \mathrm{kg}, 40 \mathrm{mg} / \mathrm{kg}, 20 \mathrm{mg} / \mathrm{kg}$, and $10 \mathrm{mg} / \mathrm{kg}$ ) of the tested compounds. Similarly, for the determination of median toxic dose $\left(\mathrm{TD}_{50}\right)$, mice were given a range of i.p. doses $(100 \mathrm{mg} / \mathrm{kg}$, $300 \mathrm{mg} / \mathrm{kg}, 500 \mathrm{mg} / \mathrm{kg}, 700 \mathrm{mg} / \mathrm{kg}$, and $900 \mathrm{mg} / \mathrm{kg}$ ) of the tested compounds. These data were subjected to Graphpad prism 5 to calculate the ED50, TD50 and the $95 \%$ confidence interval.

\section{Conclusions}

A novel series of benzenesulfonamide derivatives containing 4-aminobenzenesulfonamide and $\alpha$-amides branched valproic acid or 2,2-dimethylcyclopropanecarboxylic acid moieties were synthesized in good yields and screened for their anticonvulsant activities in MES and scPTZ test. Compounds 12c, 12d and 18b showed outstanding anticonvulsant activities in the MES test or scPTZ test. The highest activity in the MES test was observed for compound $\mathbf{1 8 b}$ with an ED50 value of $16.36 \mathrm{mg} / \mathrm{kg}$. The most active compound in the scPTZ test was compound 12c, which was seven times more active than that of valproate. Meanwhile, these three compounds have lower toxicity compared to phenytoin. The least toxic compound was compound 12d, with a $\mathrm{LD}_{50}$ value of $992.0 \mathrm{mg} / \mathrm{kg}$, which was nine times more than that of phenytoin. All three of these compounds exhibited better protective index than phenytoin and valproate, which indicated they can be used as lead compounds for future investigation to discover more effective and safer anticonvulsant drugs.

\section{Supplementary Materials}

Supplementary materials can be accessed at: http://www.mdpi.com/1420-3049/20/09/17585/s1.

\section{Acknowledgments}

This work was partially supported by the National Mega Project on Major Drug Development (2011ZX09401-302), International S \& T Cooperation Program of China (2015DFA30440, 2014DFB30020), NSFC (No.81402882, 21102107, 81273363, 81373254, 81301268 and 21390402), NSFHP (2014CFB704), the National Science and Technology Major Project of the Ministry of Science and Technology of China (No. 2012ZX10004801-003-011), the Applied Basic Research Program of Wuhan Municipal Bureau of Science and Technology (2015060101010031), and the Fundamental Research Funds for the Central Universities.

\section{Author Contributions}

Xuechuan Hong and Xiaoju Zhou conceived, designed the study and revised the paper. Zhiming Wang and Jinping Li performed the experiments, analyzed the data and wrote the manuscript. Xiaodong Zeng contributed to the synthesis of the compounds. Xianming Hu supervised the project. All authors contributed to this study, read and approved the final manuscript. 


\section{Conflicts of Interest}

The authors declare no conflict of interest.

\section{References}

1. Gitto, R.; Caruso, R.; Pagano, B.; de Luca, L.; Citraro, R. Novel potent anticonvulsant agent containing a tetrahydroisoquinoline skeleton. J. Med. Chem. 2006, 49, 5618-5622.

2. Shank, R.P.; Gardocki, J.F.; Streeter, A.J. An overview of the preclinical aspects of topiramate: Pharmacology, pharmacokinetics, and mechanism of action. Epilepsia 2000, 41, 3-9.

3. Castel-Branco, M.M.; Alves, G.L.; Figueiredo, I.V. The maximal electroshock seizure (MES) model in the preclinical assessment of potential new antiepileptic drugs. Method Find. Exp. Clin. Pharmacol. 2009, 31, 101-106.

4. Deng, X.Q.; Song, M.X.; Zheng, Y.; Quan, Z.S. Design, synthesis and evaluation of the antide-pressant and anticonvulsant activities of triazole-containing quinolinones. Eur. J. Med. Chem. 2014, 73, 217-224.

5. Sun, X.Y.; Zhang, L.; Wei, C.X.; Piao, H.R.; Quan, Z.S. Design, synthesis of 8-alkoxy-5,6-dihydro$[1,2,4]$ triazino[4,3-a]quinolin-1-ones with anticonvulsant activity. Eur. J. Med. Chem. 2009, 44, $1265-1270$.

6. Wang, S.B.; Jin, P.; Li, F.N.; Quan, Z.S. Synthesis and anticonvulsant activity of novel purine derivatives. Eur. J. Med. Chem. 2014, 84, 574-583.

7. Challal, S.; Buenafe, O.E.; Queiroz, E.F.; Maljevic, S.; Crawford, A.D. Zebrafish bioassay-guided micro-fractionation identifies anticonvulsant steroid glycosides from the Philippine medicinal plant solanum torvum. ACS Chem. Neurosci. 2014, 5, 993-1004.

8. White, H.S. Clinical significance of animal seizure models and mechanism of action studies of Potential antiepileptic drugs. Epilepsia 1997, 38, 9-17.

9. White, H.S. Preclinical development of antiepileptic drugs: past, present, and future directions. Epilepsia 2003, 44, 2-8.

10. Merritt, H.H.; Putnam, T.J. A new series of anticonvulsant drugs tested by experiments on animals. Arch. Neurol. Psychiatry 1938, 39, 1003-1015.

11. Nau, H.; Hauck, R.S.; Ehlers, K. Valproic acid-induced neural tube defects in mouse and human: Aspects of chirality, alternative drug development, pharmacokinetics and possible mechanisms. Pharmacol. Toxicol. 1991, 69, 310-321.

12. Kaneko, S.; Battino, D.; Andermann, E.; Wada, K. Congenital malformations due to antiepileptic drugs. Epilepsy Res. 1999, 33, 145-158.

13. Chang, T.K.; Abbott, F.S. Oxidative stress as a mechanism of valproic acid-associated hepatotoxicity. Drug Metab. Rev. 2006, 38, 627-639.

14. Bojic, U.; Elmazar, M.M.A.; Hauck, R.S.; Nau, H. Further branching of valproate-related carboxylic acids reduces the teratogenic activity, but not the anticonvulsant effect. Chem. Res. Toxicol. 1996, 9, 866-870.

15. Neuman, M.G.; Shear, N.H.; Jacobson-Brown, P.M. CYP2E1 mediated modulation of valproic acid-induced hepatocytotoxicity. Clin. Bio. Chem. 2001, 34, 211-218. 
16. Bojic, U.; Ehlers, K.; Ellerbeck, U.; Bacon, C.L.; Nau, H. Studies on the teratogen pharmaco-phore of valproic acid analogues: Evidence of interactions at a hydrophobic centre. Eur. J. Pharmacol. 1998, 354, 289-299.

17. Gravemann, U.; Volland, J.; Nau, H. Hydroxamic acid and fluorinated derivatives of valproic acid: Anticonvulsant activity. Neurotoxicol. Teratol. 2008, 30, 390-394.

18. Eyal, S.; Meir, B.; Boris, Y. Tetramethylcyclopropyl analogue of a leading antiepileptic drug, valproic acid. Synthesis and evaluation of anticonvulsant activity of its amide derivatives. J. Med. Chem. 2004, 47, 4316-4326.

19. Shimshoni, J.A.; Bialer, M.; Yagen, B. Synthesis and anticonvulsant activity of aromatic tetramethylcyclopropane-carboxamide derivatives. Bioorg. Med. Chem. 2008, 16, 6297-6305.

20. Neta, P.; Meir, B.; Bogdan, W.; Richard, H.F.; Boris, Y. $\alpha$-Fluoro-2,2,3,3-tetra methylcyclopropanecarboxamide, a novel potent anticonvulsant derivative of a cyclic analogue of valproic acid. J. Med. Chem. 2009, 52, 2233-2242.

21. He, X.; Qiu, G.; Yang, J.; Xiao, Y. Synthesis and anticonvulsant activity of new 6-methyl-1-substituted4,6-diazaspiro[2.4] heptane-5,7-diones. Eur. J. Med. Chem. 2010, 45, 3818-3830.

22. He, X.; Zhong, M.; Zhang, T.; Yang, J. Synthesis and anticonvulsant activity of 1-(8-(benzyloxy) quinolin-2-yl)-6-substituted-4,6-diazaspiro[2,4]heptane-5,7-diones. Eur. J. Med. Chem. 2012, 48, $338-346$.

23. Zhu, Q.; Pan, Y.; Xu, Z.; Li, R. Synthesis and potential anticonvulsant activity of new $N$-3-substituted 5,5-cyclopropanespirohydantoins. Eur. J. Med. Chem. 2009, 44, 296-302.

24. He, X.; Zhong, M.; Zhang, T.; Wu, W. Synthesis and anticonvulsant activity of ethyl 1-(2-arylhydrazine carboxa-mido)-2,2-dimethylcyclopropanecarboxylate derivatives. Eur. J. Med. Chem. 2012, 54, $542-548$.

25. He, X.; Zhong, M.; Yang, J.; Wu, Z. Synthesis and anticonvulsant activity of 1-(2-(8-(benzyloxy) quinolin-2-yl)-1-butyrylcyclopropyl)-3-substituted urea derivatives. Chem. Biol. Drug Des. 2012, $79,771-779$.

26. Zhong, M.; Zhang, Y.; He, X. Synthesis and anticonvulsant activity of ethyl 2,2-dimethyl-1-(2substitute-dhydrazinecarboxamido) cyclopropanecarboxylate derivatives. Chem. Biol. Drug Des. 2014, 84, 234-241.

27. Harish, K.P.; Mohana, K.N.; Mallesha, L. Synthesis of novel 1-[5-(4-methoxy-phenyl)-[1,3,4]oxadiazol2-yl]-piperazine derivatives and evaluation of their in vivo anticonvulsant activity. Eur. J. Med. Chem. 2013, 65, 276-283.

28. Swinyard, E.A. Laboratory evaluation of antiepileptic drugs. Epilepsia 1969, 10, 107-119.

29. Dunham, N.W.; Miya, T.A. A note on a simple apparatus for detecting neurological deficit in rat and mice. J. Am. Pharm. Assoc. Sci. 1957, 46, 208-209.

30. Dimmock, J.R.; Pandey, S.N.; Quail, J.W. Evaluation of the semicarbazones, thiosemicarbazones and biscarbohydrazones of some aryl alicyclic ketones for anticonvulsant and other biological properties. Eur. J. Med. Chem. 1995, 30, 303-314.

31. Rajak, H.; Deshmukh, R.; Aggarwal, N. Synthesis of novel 2,5-disubstituted 1,3,4-thiadiazoles for their potential anticonvulsant activity: Pharmacophoric model studies. Arch. Pharm. 2009, 342, 453-461. 
32. Fraser, H.F.; Wikler, A.; Essig, C.F. Degree of physical dependence induced by secobarbital or pentobarbital. J. Am. Med. Assoc. 1958, 166, 126-129.

33. Ucar, H.; Kim, V.D.; Cacciaguerra, S.; Spampinato, S. Synthesis and anticonvulsant activity of 2 (3H)-benzoxazolone and 2 (3H)-benzothiazolone derivatives. J. Med. Chem. 1998, 41, 1138-1145.

34. Azam, F.; El-Gnidi, B.A.; Alkskas, I.A. Combating oxidative stress in epilepsy: design, synthesis, quantum chemical studies and anticonvulsant evaluation of 1-(substituted benzylidene/ethylidene)4-(naphthalen-1-yl)semicarbazides. Eur. J. Med. Chem. 2010, 45, 2817-2826.

35. Swinyard, E.A.; Brown, W.C.; Goodman, L.S. Comparative assays of antiepileptic drugs in mice and rats. J. Pharmacol. Exp. Ther. 1952, 106, 319-330.

36. Vamecq, J.; Lambert, D.; Poupaert, J.H.; Masereel, B.; Stables, J.P. Anticonvulsant activity and interactions with neuronal voltage-dependent sodium channel of analogues of ameltolide. J. Med. Chem. 1998, 41, 3307-3313.

Sample Availability: Samples of the compounds are available from the authors.

(C) 2015 by the authors; licensee MDPI, Basel, Switzerland. This article is an open access article distributed under the terms and conditions of the Creative Commons Attribution license (http://creativecommons.org/licenses/by/4.0/). 